\title{
Melden Sie noch bis zum 28. Februar Ihren Hellsten Kopf an!
}

"Die hellsten Köpfe für die Radiologie“ noch bis zum 28. Februar 2019 können Sie als Patin oder Pate Ihre eigenen Hellsten Köpfe benennen. Das können Studierende, Famulanten/Famulantinnen oder PJler sein, die mit Hilfe des Programms einen tiefen Einblick in den Deutschen Röntgenkongress erhalten. Der Kongress vom 29. Mai bis 1. Juni 2019 ist zudem ein besonderer: es ist der 100. RöKo und damit ein Jubiläumskongress! Mehr Infos gibt es auf www.roentgenkongress.de. Mit der Initiative wollen die Deutsche Röntgengesellschaft (DRG) und der Berufsverband der Deutschen Radiologen (BDR) den radiologischen Nachwuchs sichern.

\section{So geht's:}

Die Anmeldung Ihrer Hellsten Köpfe läuft über die DRG-Geschäftsstelle.

Auf www.hellste-koepfe.de finden Sie alle wichtigen Informationen.

Ihre Fragen beantworten wir gerne unter hellste-koepfe@drg.de.

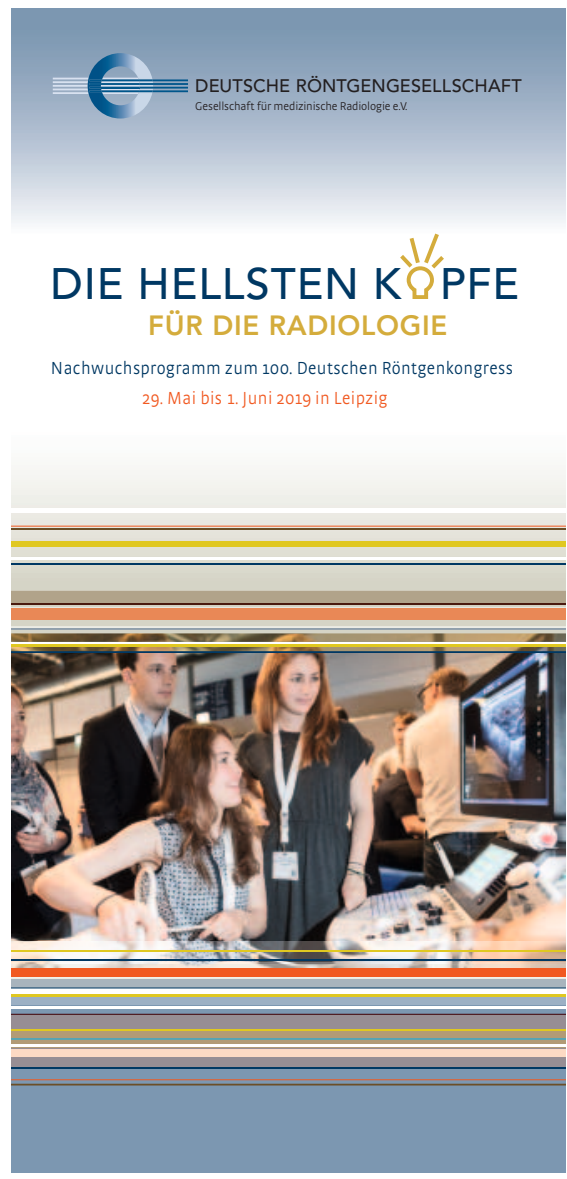

